\title{
Is language natural to man? Some historical considerations Willem JM Levelt
}

Since the Enlightenment period, natural theories of speech and language evolution have florished in the language sciences. Four ever returning core issues are highlighted in this paper: Firstly, Is language natural to man or just an invention? Secondly, Is language a specific human ability (a 'language instinct') or does it arise from general cognitive capacities we share with other animals? Thirdly, Has the evolution of language been a gradual process or did it rather suddenly arise, due to some 'evolutionary twist'? Lastly, Is the child's language acquisition an appropriate model for language evolution?

\begin{abstract}
Address
Max Planck Institute for Psycholinguistics, P.O. Box 310, 6500 AH Nijmegen, The Netherlands
\end{abstract}

Corresponding author: Levelt, Willem JM (pim@mpi.nl)

Current Opinion in Behavioral Sciences 2018, 21:127-131

This review comes from a themed issue on The evolution of language Edited by Christopher Petkov and William Marslen-Wilson

For a complete overview see the Issue and the Editorial

Available online 27th April 2018

https://doi.org/10.1016/j.cobeha.2018.04.003

2352-1546/৫ 2018 Elsevier Ltd. All rights reserved.

It is often a sobering experience to become aware of the insights of our scientific predecessors. The language sciences in particular are not endowed with remarkable long term memory, as I repeatedly showed in my A History of Psycholinguistics [1]. The aim of this short note is to awaken some 'sleeping beauties' [2] in theorizing about language evolution. Many of the core issues addressed in this special issue have, often hotly, been debated since Enlightenment called into question the dominant belief that God had created us with our languages a few thousand years ago.

I have selected four such issues from a much larger set: Firstly, Is language natural to man or just an invention? Secondly, Is language a specific ability? Thirdly, Has the evolution of language been a gradual process or a sudden evolutionary twist? Lastly, Is the evolution of language based on the child's 'language instinct'? These four issues are not independent, but working out their relations is beyond the scope of this note.

\section{Is language natural to man or just an invention?}

The Scottish lawyer, philosopher and linguist James Burnett, alias Lord Monboddo, raised the issue 'Is articulation natural to man?' in his 6-volume The Origin and Progress of Language (1773-1792) [3], that is, is it natural for man to speak? His answer was a resounding 'no' 'Articulation is altogether the work of art'. First, 'of all savages [i.e. feral children/people] which have been caught in different parts of Europe, not one had the use of speech, though they had all organs of pronunciation such as we have them'. Second, 'not only solitary savages, but a whole nation, if I may call them so, have been found without the use of speech'. This special people, described by naturalist Buffon [4], are 'the Orang Outangs, that are found in the kingdom of Angola', see Figure 1. They are human, 'walking erect', 'use sticks for weapons', 'live in a society', 'make huts', etc., but 'they have not advanced so far as to invent language'. Twenty years earlier, JeanJacques Rousseau had already argued that our primordial ancestors had no language 'because for people who lack any mutual relationship, nor had any need for it, one can neither conceive the necessity of such an invention, nor its possibility' [5].

Johann Gottfried Herder gave short shrift to such musings. In his preface to the 1784 German translation of Monboddo's treatise, he politely but strongly rejected Monboddo's claim that there are peoples without language. Orang Utangs are not people but apes. Here Herder refers to the work of the great Dutch comparative anatomist Peter Camper, who showed that the Orang's vocal tract differs from the human organ and is unfit to produce speech [6], foreshadowing Lieberman et al. [7].

Herder had earlier written in his prize-winning essay [8]: 'the genesis of language is an inner pressure much like an embryo's pressure for birth at the moment of gestation'. 'Without language', he wrote, 'man has no mind [Vernunft] and without mind no language'. That 'language is natural to man' remained the dominant view in the literature. Wolfgang von Kempelen, the greatest speech scientist of his era, discussed the origins of language in his wonderful 1791 book on the mechanisms of speech [9]. He had visited l'Abbé de l'Epée in Paris, who had founded the first Institute for the Deaf. There he had observed that this community had invented a language 'brought to the same level of completeness as our normal spoken language'. Languages, whether 
Figure 1

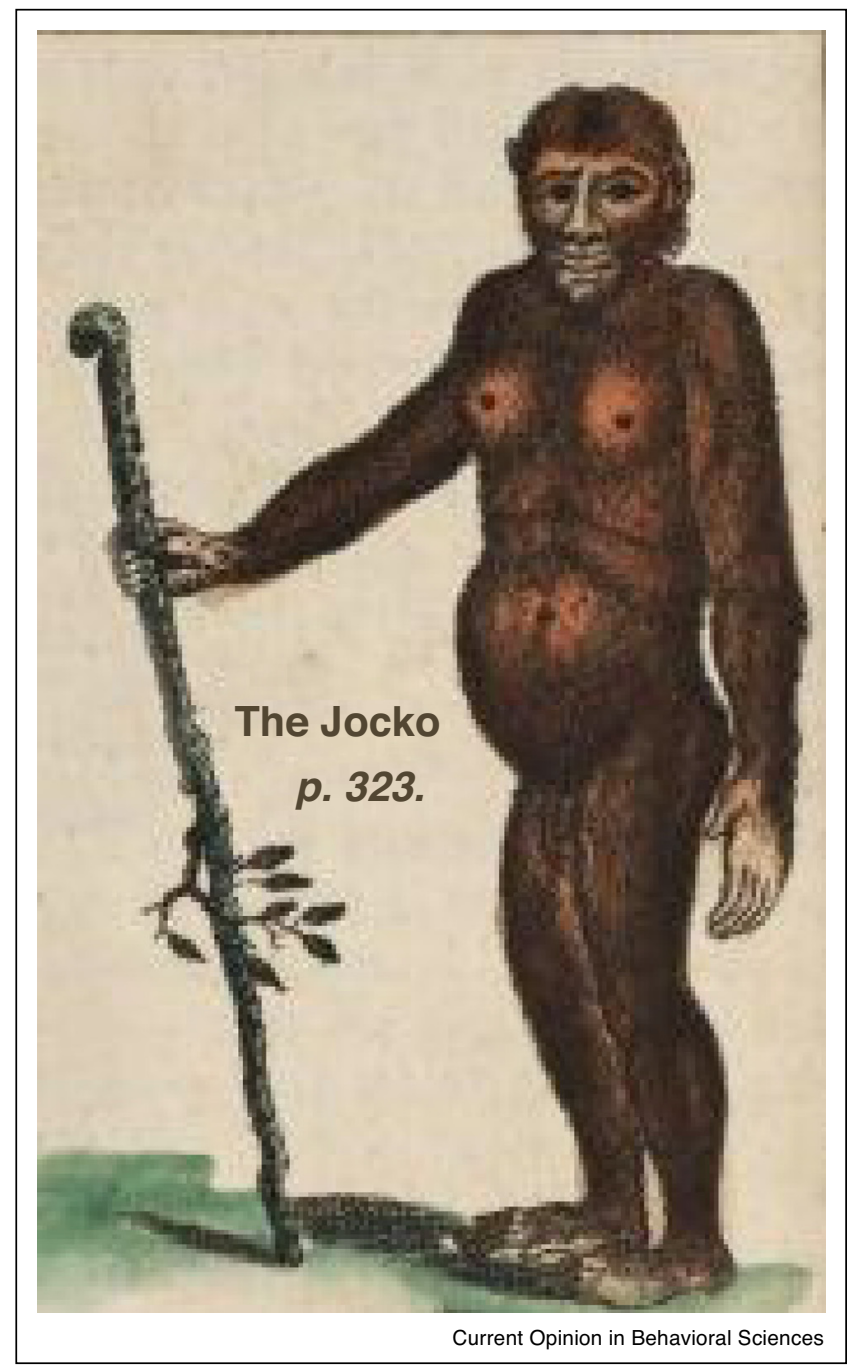

The Jocko. The small 'Orang Utang" as presented in the abridged English language edition of Buffon's Histoire Naturelle [4]. According to Monboddo, they were human beings, though without language. The term 'Orang Utang" was occasionally applied to any ape.

signed or spoken, spontaneously arise in human communities, he wrote. This view was shared with most 19th century language scholars, such as Humboldt, Steinthal and Müller.

The versatile Canadian linguist/anthropologist Horatio Hale wrote in 1883 about the speech of early humans: 'If those who used this primitive speech were - as we must suppose them to have been - human beings like those who now exist, their language was a language complete in all its parts: for no tribe of men has been found in any part of the world so low in the scale of humanity as not to have a complete and thoroughly organized language.' [10], p. 282. We will return to Hale's views on the origin of languages below.

\section{Is language a specific ability?}

In his The descent of man [11] Darwin cited the then famous linguist Max Müller: 'A struggle for life is constantly going on amongst the words and grammatical forms in each language. The better, the shorter, the easier forms are constantly gaining the upper hand, and they owe their success to their own inherent virtue.' Notice first how Müller anticipated Dennett, for whom words are the prototype of memes. In [12] he writes 'in memetic evolution it is the fitness of the memes themselves that is at stake, not the fitness of their hosts.' But Müller disagreed with Darwin on the specificity of language: 'By no effort of the understanding, by no stretch of the imagination, can I explain to myself how language could have grown out of anything which animals possess, even if we granted them millions of years for that purpose... Language is our Rubicon, and no brute will dare to cross it'. In a personal conversation with Darwin, Müller therefore suggested that there had been 'a fifth progenitor for man', next to Darwin's four. Darwin had kindly responded: 'You are a dangerous man'. [13], p. 153.

Darwin disagreed. Language is not innate to man. Like the song of birds it has to be learned by imitation from the parents. This 'instinctive tendency to acquire an art is not peculiar to man.' [11], p. 59. But others, such as Horatio Hale [10] and George Romanes [14] stressed the existence of a unique 'language instinct' in man.

\section{Has the evolution of language been a gradual process or a sudden evolutionary twist?}

The overwhelming opinion of language scholars since the Enlightenment has been that language is the product of a gradual evolution, a co-evolution of language and human intellect. Herder [8] had called this 'reflective consciousness'. It allowed us to attend to the 'sounds of nature' and to make reference to objects or events by vocally imitating their sounds. Steinthal [15] described in great technical detail how our cognitive ability of 'apperception' (as opposed to mere 'association') creates our conscious links between sounds and meanings, ultimately resulting in a first primordial vocabulary (see my [1], pp. 42-48, for details of this theory). Max Müller [16] adopted Noiré's [17] idea that our first lexical roots emerged from the sounds produced during our joint social activities, such as weaving, building vessels and cooking.

Wilhelm Wundt reviewed the dominant theories of language origins in his Die Sprache of 1900 [18]. If language and cognition/intellect are fully intertwined, he argued, there are two possible conceptions of the origins of language: There has been a gradual co-evolution of both, or both more or less suddenly appeared by some crucial event during our evolution. Wundt called this latter variety 'the miracle theories'. The original miracle theory had, of course, been the godly endowment of language in our species. 
Wundt discusses some miracle-like theories, but misses the most remarkable one, Horatio Hale's [10]. Hale had joined the paleontologists of his time in claiming that paleolithic homo alalus, now extinct, was a speechless hunter-gatherer. The Neanderthal man, discovered in 1856 , was one of them. But then, in a rather recent twist of evolution, modern man appeared, scattering all over the world. Wherever they settled, they were in possession of a fully developed, complex spoken language. Hale estimated the appearance of speaking modern man at some 10000 years ago. European Cro-Magnon or cave-man was the best-studied example.

How did this speaking homo variety evolve so suddenly? According to Hale a noteworthy difference between the early and the recent homo skulls is the 'low and receding forehead' of the original race and the high forehead of recent homo. This must be due to evolutionary recent frontal lobe development, in particular of the third frontal convolution, which now became the largest of the three. That convolution contains Broca's speech area. How could this have come about? Let me cite Hale: 'There can be no question that this variety arose in the usual way, by what is termed the process of heterogenesis, or, in other words, the law by which offspring differs from parents.', that is, by mutation. This is no different from what has suddenly created polydactilism, hands with six fingers, in a family. In comparison to polydactilism the mutation causing the third convolution to enlarge was a 'change of the minutest kind', according to Hale, but one with enormous consequences, here citing famous evolutionist Thomas Huxley: 'The moral and intellectual difference between them and ourselves would be practically infinite, though the naturalist should not be able to find a single shadow even of specific structural difference.'

This miracle theory also became a sleeping beauty, lovingly awakened by Berwick and Chomsky [19], p. 79, in their attempt to account for the sudden appearance of our recursive language capacity: "Merge . . . may have risen from something as straightforward as a slight rewiring of the brain, perhaps only a slight extension of existing cortical 'wiring'."

\section{Is the evolution of language based on the child's 'language instinct'?}

Charles De Brosses, man of letters from Dijon and contributor to Diderot's Encyclopédie, published his impressive work on etymology [20] in 1765 . The roots of our primordial language cannot be reconstructed according to De Brosses. All resemblance with existing languages has been lost in the course of history. To discover the origins of language, we better focus on those who begin to speak, 'ce sont les enfants'. This ontogenetic perspective, introduced by De Brosses, kept returning in the literature till the present day: 'Language acquisition is a model of language evolution in our species' Lila Gleitman argued in her 2017 APS Lecture [21].

Steinthal wrote in 1855 [22]: 'the laws that are still today operative in the child's acquisition of language, were also the driving forces in the invention of language.' Schultze, writing on the acquisition of speech sounds in children [23], expressed the same perspective: 'but doesn't the miracle of recruiting language confront us anew in any child? Couldn't one reconceive, in the developmental process of individual life, the fluid phenomena, which long since rushed by in the stream of universal development?'

Hippolyte Taine wrote in his 1877 Mind paper on language acquisition [24]: 'Speaking generally, the child presents in a passing state the mental characteristics that are found in a fixed state in primitive civilizations'. This expressed Haeckel's so-called 'biogenetic law' [25], ontogeny recapitulating phylogeny, which was, for the case of language acquisition, a Lamarckian confusion of cultural and biological evolution.

Horatio Hale [10] came up with an explanation for child language being the source of all language evolution: 'If a single pair, man and wife, should wander off into an inhabited region, and there, after a few years, both perish, leaving a family of young children to grow up by themselves and frame their own speech, ... this speech might, and probably would, be an entirely novel language... The baby-talk, ..., would become the mother-tongue of the new community. Briefly then ... the origin of linguistic stocks is to be found in what may be termed the language-making instinct of very young children.'

But no-one went into so much, well observed detail as De Brosses [20] himself. Children 'mechanically' (i.e. are biologically disposed to) start expressing their 'sentiments' by way of interjections, different feelings affecting different speech organs. They mechanically babble and these bilabial and dental babbles become the first roots of words (such as papa, mama) in all languages. They equally mechanically imitate the sounds they hear, creating their first onomatopoeias. With similar necessity they exercise sound symbolism and metaphor.

The ultimate test for the existence of a language instinct, we all know, was performed by Pharao Psammetichus I during the 7 th century B.C. The two infants he ordered to be brought up in an isolated place without speech input, produced as their first frequent word becos, which is Phrygian for 'bread', such proving that speech is indeed innate and discovering the original language.

This experiment has met with minor ethical objections, but has it ever been replicated as a natural experiment? Horatio Hale was probably the first to collect the relevant 
evidence in his cited 1886 paper. He discussed five reported cases of idiosyncratic speech jointly invented by pairs of small children, but incomprehensible to the environment. Two of these couples were twins, all were inseparable mates. For one of them, a four-year old girl and younger brother in Albany, Dr. Hun published a report in the 1868 Journal of Psychological Medicine. It provides 21 words from their vocabulary plus various utterances, from which rules of construction could be derived, such as reduplications and post-positioning of adjectives. It even mentions a case where the girl corrects the boy's mispronunciation of a word, gna-mignar instead of gummigar, which means 'cook'.

Doctor Hun's paper is the mother of studies in idioglossia, private languages, often observed as emerging in twins. These always turn out to be (hardly intelligible) 'pidgins' of languages in the environment. Hence, they are less than optimal replications of Psammetichus' experiment. Far better replications have emerged over the last two decades in studies of sign language, in particular studies of 'homesign' and of sign languages newly emerging in Deaf communities. Homesign develops in deaf children who cannot acquire spoken language and are not exposed to sign language, and who cannot read or write the environment's language. A fascinating range of studies by Goldin-Meadow, Newport and their co-workers - see [26] for a review - revealed that these self-created systems show a range of linguistic features that are different from the co-speech gestures used by the parents of these deaf children. For instance, home signers use utterance initial position to mark grammatical subject. They use handshape to mark agentivity. Homesigners in China, the US and Turkey all use ergative constituent ordering, hence different from the ambient spoken languages and absent in co-speech gesturing. Complex hierarchical structures appear in nominative expressions, etcetera. Clearly, in Horatio Hale's terms, we see the deaf child's language instinct at work.

Still, comparisons to established sign languages show that homesign systems, although clearly linguistic, are not fullfledged sign languages. Senghas and Copolla's classical study [27] demonstrated that it takes two (or more) to tango, as Psammetichus had already presumed. They studied the emergence of a new sign language in the newly established educational Deaf community in Managua, Nicaragua. These deaf students had not been exposed to sign languages. They had grown up as homesigners, without any common system of communication. This first cohort quickly developed their own shared signing system, a pidgin-type language. The authors, and many more interacting with them, not only carefully documented this system, but also the sign language developing in the second cohort, that is, the new students later entering the pidgin-language cohort. It is beyond the scope of the present paper to review this work in detail. Its main conclusion, however, is that a fully-fledged new sign language had emerged in the third cohort.

Horatio Hale would have loved this proof of the existence of a 'language-making instinct' in children, the requirement of a community to launch it and the need of a few generations for it to create an entirely new language.

\section{Conclusion}

No digging the African soil will ever uncover traces of our primordial spoken languages. That fact alone invited the proliferation of theories of language evolution over many centuries of linguistic scholarship. We have learned that language evolution keeps repeating itself; the same is bound to occur to theories of language evolution.

\section{Conflict of interest statement}

Nothing declared.

\section{References}

1. Levelt WJM: A History of Psycholinguistics. The pre-Chomskyan Era. Oxford University Press; 2014.

2. Levelt WJM: Sleeping beauties. In Structures in the Mind. Essays on Language, Music, and Cognition in Honor of Ray Jackendoff. Edited by Toivonen I, Csúri P, Van der Zee E. MIT Press; 2015: 235-256

3. Burnett J: The Origins and Progress of Language. Kincaid \& Creech; 1773-1792.

4. Buffon GLL: Histoire Naturelle, générale et particulière . Imprimerie royale; 1766 .

5. Rousseau JJ: Discours sur l'origine et les fondements de l'inégalite' parmi les hommes Marc Michel Rey. 1755.

6. Herder JG: Vorrede. In Des Lord Monboddo Werk von dem Ursprunge und Fortgange der Sprache. Edited by Schmid Übersetzt von Gulbr, Hartknoch JF. 1784.

7. Lieberman P, Klatt DL, Wilson WA: Vocal tract limitations on the vowel repertoires of rhesus monkey and other nonhuman primates. Science 1969, 164:1185-1187.

8. Herder JG: Abhandlung über den Ursprung der Sprache. Voss. 1772.

9. von Kempelen W: Mechanismus der menschlichen Sprache nebst der Beschreibung einer sprechenden Machine. JB Degen; 1791.

10. Hale $\mathrm{H}$ : The origin of language and the antiquity of speaking man. Proc AAAS 1886, 35:1-47.

11. Darwin C: The Descent of Man. John Murray; 1871.

12. Dennett D: From Bacteria to Bach and Back. The Evolution of Minds. WW Norton; 2017.

13. Müller M: The Science of Thought. Longmans: Green and Co.; 1887.

14. Romanes G: Mental Evolution in Man: Origin of Human Faculty. Kegan Paul; 1889.

15. Steinthal H: Einleitung in die Psychologie und Sprachwissenschaft. F. Dümmler; 1871

16. Müller M: The Science of Language. Longmans: Green and Co.; 1887.

17. Noiré L: Der Ursprung der Sprache. Victor v. Zabern; 1877.

18. Wundt W: Die Sprache. Engelman; 1900. 
19. Berwick RC, Chomsky N: Why Only Us. Language and Evolution MIT Press; 2016.

20. De Brosses C: Traité de Formation des Langages et des Principes Physiques de l'Étymologie. Tome I. Terrelongue 1765.

21. Gleitman LR: Rome wasn't built in a day, but maybe Latin was 29th Annual APS Conference; Boston: 2017.

22. Steinthal H: Grammatik, Logik und Psychologie. Ihre Prinzipien und ihr Verhältniss zueinander. F Dümmler; 1855.

23. Schultze F: Die Sprache des Kindes. Kosmos 1880, 4:23-41.
24. Taine $\mathrm{H}$ : Acquisition of language by children. Mind 1877, 2 : 252-259.

25. Haeckel E: Anthropogenie oder Entwicklungsgeschichte des Menschen. W. Engelmann; 1874.

26. Brentari D, Goldin-Meadow S: Language emergence. Annu Rev Linguist 2017, 3:363-388.

27. Senghas A, Coppola M: Children creating language: how Nicaraguan Sign Language acquired a spatial grammar. Psychol Sci 2001, 12:323-328. 